Rakenteiden Mekaniikka (Journal of Structural Mechanics)

vol. 53, nro. 4, 2020, s. 304-307

http://rakenteidenmekaniikka.journal.fi/index

https://doi.org/10.23998/rm.85834

(C) 2020 kirjoittajat

Vapaasti saatavilla CC BY 4.0 -lisenssin mukaisesti

\title{
Virtuaalisesta siirtymästä
}

Eero-Matti Salonen ${ }^{1}$ ja Mika Reivinen

Tiivistelmä Artikkelissa tarkastellaan ainefaasien välisen faasipinnan teoreettista käsittelyä virtuaalisen työn periaatteen avulla. Virtuaalisen siirtymän käsite vaatii tällöin tavanomaisesta poikkeavan tulkinnan.

Avainsanat: virtuaalinen siirtymä, todellinen siirtymä, faasipinnan asema

Vastaanotettu: 11.10.2019. Hyväksytty: 10.1.2020. Julkaistu verkossa: 20.10.2020.

\section{Johdanto}

Mekaniikassa ja erityisesti rakenteiden mekaniikassa on totuttu siihen, että virtuaalinen siirtymä $\delta \mathbf{r}$ tulkitaan (kontinuumi)partikkelin kokeman todellisen siirtymän $\mathbf{u}$ variaatioksi: $\delta \mathbf{r}=\delta \mathbf{u}$. Sisäisten voimien eli jännitysten tekemän virtuaalisen työn laskennassa voidaan silloin hyödyntää suoraan todellisten venymäkomponenttien lausekkeista variaatiolaskennan sääntöjen mukaan johdettuja virtuaalisia venymäkomponentteja.

Tämän kirjoittajat ovat soveltaneet virtuaalisen työn periaatetta ainefaasien rajapintojen eli faasipintojen asemien määrittämiseen; esimerkiksi [1], [2]. Virtuaalisen siirtymän käsite vaatii näissä sovelluksissa äskeisestä poikkeavan tulkinnan. Oleellista on, että tarkasteluun ei voida enää liittää käsitettä partikkelin (todellinen) siirtymä.

\section{Tavanomainen tulkinta}

Tarkastellaan esimerkkinä kaksidimensioista tapausta ja olkoon käytössä karteesiset suorakulmaiset $x, y$-koordinaatit. Partikkelin paikkavektorin esitys nykytilassa on muotoa $\mathbf{r}(x, y)=\mathbf{r}_{0}(x, y)+\mathbf{u}(x, y)$, jossa indeksi 0 viittaa partikkelin alkuasemaan ja jossa $\mathbf{u}$ on partikkelin siirtymä alkutilan suhteen. Koska $\mathbf{r}_{0}$ on varioinnin suhteen vakio, variointi antaa tuloksen

$$
\delta \mathbf{r}=\delta \mathbf{u}
$$

\footnotetext{
${ }^{1}$ Vastuullinen kirjoittaja: eeromatti.salonen@gmail.com
} 
eli virtuaalinen siirtymä voidaan tulkita siirtymän variaatioksi. Normaalisti alan kirjallisuudessa operoidaankin virtuaalisen työn periaatteen sovelluksissa nimenomaan todellisen siirtymän $\mathbf{u}$ variaation $\delta \mathbf{u}$ avulla.

Esimerkiksi pienten siirtymien teoriassa jännityskomponenttiin $\sigma_{x}$ liitetyn venymäkomponentin $\varepsilon_{x}$ lauseke on

$$
\varepsilon_{x}=\frac{\partial u}{\partial x}
$$

jossa $u$ on $x$-akselin suuntainen siirtymäkomponentti. Variointi antaa siten varioinnin laskusääntöjä käyttäen virtuaalisen venymäkomponentin

$$
\delta \varepsilon_{x}=\delta \frac{\partial u}{\partial x}=\frac{\partial \delta u}{\partial x}
$$

joka kertoo komponentin $\sigma_{x}$ (miinusmerkkisenä) sisäisten voimien virtuaalista työtä laskettaessa.

Suurten siirtymien teoriaa sovellettaessa jännityskomponenttia (toinen Piolan-Kirchhoffin jännitys) $S_{x x}$ vastaavan venymäkomponentin $E_{x x}$ lauseke on

$$
E_{x x}=\frac{\partial u}{\partial x}+\frac{1}{2}\left[\left(\frac{\partial u}{\partial x}\right)^{2}+\left(\frac{\partial v}{\partial x}\right)^{2}\right]
$$

jossa $v$ on $y$-akselin suuntainen siirtymäkomponentti. Variointi antaa nyt virtuaalisen venymäkomponentin

$$
\delta E_{x x}=\frac{\partial \delta u}{\partial x}+\frac{\partial u}{\partial x} \frac{\partial \delta u}{\partial x}+\frac{\partial v}{\partial x} \frac{\partial \delta v}{\partial x}
$$

joka kertoo komponentin $S_{x x}$ (miinusmerkkisenä) sisäisten voimien virtuaalista työtä laskettaessa.

\section{Siirtymä ei ole käytettävissä}

Olkoon kohteena kahden ainefaasin välisen faasipinnan (engl. interface) aseman määrittäminen virtuaalisen työn periaatteen avulla. Tarkastellaan johdantona kuvaa 1. Kuva 1 (a) esittäköön (äärettömän ohueksi otaksutun) kalvorakenteen poikkileikkausta ja kuva 1

(b) faasipinnan poikkileikkausta.

Kuvissa esitetty kalvon liike ja faasipinnan aseman muutos voisivat johtua vaikka ympäristössä vallitsevan paineen muutoksesta. Oleellista on, että liikkeen jälkeen kalvo muodostuu samoista partikkeleista kuin alkuasemassa. Kyseessä on termodynamiikan sanastoa käyttäen niin sanottu suljettu systeemi (engl. closed system). Itse asiassa kaikki tavanomaiset kappaleet rakenteiden mekaniikassa ovat suljettuja systeemeitä. Jos nyt kuvassa 1 (a) partikkeli pisteessä $\mathrm{P}$ on siirtynyt pisteeseen $\mathrm{Q}$, partikkeli on siis saanut paineen muutoksen yhteydessä siirtymän $\mathbf{u}=\overrightarrow{P Q}$. 
Kuvan 1 (b) tapauksessa faasipinta voi muodostua katkoviivoitetussa asemassa osittain tai täysin eri partikkeleista kuin yhtenäisellä viivoituksella esitetyssä asemassa. Pinnan aseman muutoksen yhteydessä voi myös tapahtua vaikka sulamista tai jähmettymistä (engl. melting or solidification). Esimerkiksi ylöspäin suuntautuneen jähmettymisen yhteydessä pisteessä $\mathrm{P}$ ollut partikkeli on voinut pysyä likimain paikoillaan (siirtymä pisteeseen Q) ja uuden faasipinnan partikkelit voivat nyt olla entisen nestefaasin partikkeleita. Ei siis voida käytännössä "pitää kirjaa" systeemin partikkelien kokemista siirtymistä. Tämä asetelma ei kuitenkaan estä virtuaalisen työn periaatteen soveltamista.

(a)

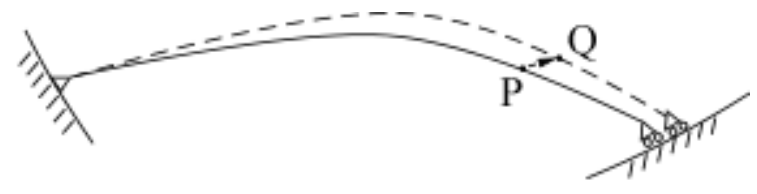

(b)

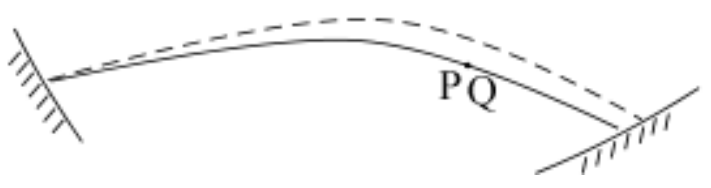

Kuva 1 (a). Kalvorakenteen kaksi mahdollista asemaa. (b) Faasipinnan kaksi mahdollista asemaa.

Tarkastellaan tilannetta vielä yksinkertaistaen otaksuen kuvan 1 (b) esittävän sylinterimäisen faasipinnan poikkileikkausta. Pinnan oletettu asema voidaan antaa vaikka muodossa $\mathbf{r}=\mathbf{r}(s)$, jossa on $\mathbf{r}$ paikkavektori ja $s$ kaarenpituuskoordinaatti. Voimme varioida suuretta $\mathbf{r}$ ja saada tulokseksi suureen $\delta \mathbf{r}$, jota voimme nimittää edelleen virtuaaliseksi siirtymäksi. Se ei ole kuitenkaan enää siirtymän variaatio. Esimerkiksi lähteissä [1], [2] on käytetty tässä yhteydessä erotuksena siirtymän variaatiosta usein nimitystä "virtual movement". Nimitys on lainattu lähteestä [3, s. 283], jossa se esiintyy erään lyhyen pintajännitykseen liittyvän johdon yhteydessä. Emme kuitenkaan ole varmoja kyseisen terminologian tarpeellisuudesta; merkintää $\delta \mathbf{r}$ voitaneen edelleen hyvin nimittää virtuaaliseksi siirtymäksi (engl. virtual displacement).

Siirrytään hetkeksi kuvan 1 (a) asetelmaan ja ajatellaan myös, että kyseessä on sylinterimäisen kalvorakenteen poikkileikkaus, jolloin voidaan jälleen käyttää esitystä $\mathbf{r}=\mathbf{r}(s)$. Olkoon siirtymä $\mathbf{u}=\overrightarrow{\mathrm{PQ}}$ pienten siirtymien teorian alainen. Ei ole vaikea osoittaa, että kalvon suuntaisen venymäkomponentin lauseke on tällöin

$$
\varepsilon=\mathbf{t} \cdot \frac{\mathrm{du}}{\mathrm{d} s},
$$

jossa $\mathbf{t}$ on mitan $s$ kasvavaan suuntaan osoittava yksikkötangenttivektori.

Palataan nyt kuvan 1 (b) yhtenäisen viivan esittämään asetelmaan ja liitetään mukaan kuviteltu "äärettömän pieni" virtuaalinen siirtymä $\delta \mathbf{r}$. Ymmärretään, että todellista pientä siirtymää $\mathbf{u}$ vastaa tässä täysin kuviteltu pieni siirtymä $\delta \mathbf{r}$ ja vastaava virtuaalinen venymäkomponentti tulee siis olemaan kaavan (6) perusteella 


$$
\delta \varepsilon=\mathbf{t} \cdot \frac{\mathrm{d}(\delta \mathbf{r})}{\mathrm{d} s} .
$$

Tätä lauseketta voidaan siis hyödyntää faasipintaan liittyvien sisäisten voimien (tässä kalvossa vallitseva normaalivoima) virtuaalisen työn laskennassa. Sovellettu ajatuskulku voidaan laajentaa mielivaltaisen kaarevan faasipinnan käsittelyyn käyttämällä pinnan esitykseen pintakoordinaatteja.

Ymmärretään myös, että koska käytettävissä ei ole todellisia siirtymiä, mitään monimutkaisia äärellisten siirtymien teoriaan liittyviä venymäkomponenttien lausekkeita kuten (4) - ei tarvitse ottaa käyttöön.

\section{Lisähuomautuksia}

Virtuaalisen työn periaatteeseen voidaan liittää tunnetusti vaihtelevia tulkintoja. Esimerkkinä voidaan lainata lähdettä [4, s. 32]: "However, from a mathematical viewpoint, it is not necessary to think of the test functions $\delta u(X)$ as virtual displacements: they are simply test functions which satisfy continuity conditions and vanish on the displacement boundaries".

Tämän artikkelin kannalta tärkeä paino- eli testifunktiota (engl. weighting or test function) $\delta \mathbf{r}$ rajoittava tulkinta on siis vain pitää sitä "pienenä", koska silloin voidaan hyödyntää pienten (todellisten) siirtymien teorian mukaisesti esitettyjä tavanomaisia venymäkomponenttien lausekkeita. Kuten on ilmeistä, kyseinen yksinkertaistava tulkinta ei aiheuta mitään käytännön ongelmia.

\section{Viitteet}

[1] M. Reivinen, E.-M. Salonen, I. Todoshchenko, V.P. Vaskelainen. Equilibrium crystal shapes by virtual work. Journal of Low Temperature Physics, Volume 170, pp. 75-90, 2013. https://doi.org/10.1007/s10909-012-0666-8

[2] M. Reivinen, E.-M. Salonen, I. Todoshchenko, V.P. Vaskelainen. Equilibrium crystal shapes by virtual work in 3D. Journal of Low Temperature Physics, Volume 180, pp. 394-415, 2015. https://doi.org/10.1007/s10909-015-1313-y

[3] D. Tabor. Gases, Liquids and Solids and Other States of Matter, third edition, Cambridge University Press, 1991.

[4] T. Belytschko, W. K. Liu, B. Moran. Nonlinear Finite Elements for Continua and Structures, Wiley, 2000.

Eero-Matti Salonen

Sibeliuksenkatu 3 B 25, 00250 Helsinki, Finland

eeromatti.salonen@gmail.com

Mika Reivinen

Sitowise Oy

Linnoitustie 6 D, 02600 Espoo, Finland

mika.reivinen@sitowise.com 